\title{
ANALISIS PERTANGGUNGJAWABAN PIDANA BAGI ANGGOTA POLRI YANG MELAKUKAN TINDAK PIDANA PENYALAHGUNAAN NARKOTIKA BERDASARKAN UNDANG-UNDANG NOMOR 35 TAHUN 2009 TENTANG NARKOTIKA
}

\author{
Sinta Ayu Lestari \\ (Mahasiswa Program S1 Fakultas Hukum Universitas Tarumanagara) \\ (E-mail: Sintaayulestari7@gmail.com)
}

\section{Hery Firmansyah, S.H., M.Hum., MPA}

(Corresponding Author)

(Dosen Fakultas Hukum Universitas Tarumanagara. Meraih Sarjana Hukum pada Fakultas Hukum Universitas Gadjah Mada, Magister Hukum pada Fakultas Hukum Universitas Gadjah Mada, Magister Administrasi pada Fakultas Public Administration Universitas Gadjah Mada)

(E-mail: heryf@fh.untar.ac.id)

\begin{abstract}
In Indonesia the problem of drug abuse and illicit trade continues to increase, worrying and endangering people's lives. Based on "Law Number 35 of 2009 concerning Narcotics which supersedes Law Number 22 Year 1997", it has been regulated regarding the prohibition on the use of narcotics which are carried out without permission. In the case of narcotics abuse there are law enforcement officers who handle one of them, the police. The police as the executor and law enforcer have the duty to safeguard security and prevent and eradicate criminal acts as stipulated in the "Republic of Indonesia Police Chief Regulation Number 14 of 2011 concerning the Professional Code of Ethics of the Republic of Indonesia National Police”. In fact, there is a case in Decree "Number 1057 / Pid.Sus / 2018 / PN.Jkt.Tim and Decree Number 906 / Pid.Sus / 2018 / PN.Jkt.Tim". where members of the police commit criminal acts of narcotics abuse. What is the mechanism of the legal process? and What is the criminal responsibility for members of the police who commit criminal acts of narcotics abuse? The author uses the normative juridical legal method and uses interview data as supporting data. The results reveal that the legal process for police officers who commit narcotics crimes similar to justice for ordinary people is in accordance with the Criminal Procedure Code, the difference is that if there is a process within the police, the police must take into consideration the profession as law enforcement in incriminating matters.
\end{abstract}


Keywords: conviction, criminal liability, police officer, narcotics abuse

\section{PENDAHULUAN}

\section{A. Latar Belakang}

Masyarakat dunia termasuk masyarakat di Indonesia pada akhir-akhir ini telah dihadapkan oleh kondisi yang sangat menghawatirkan akibat semakin maraknya pemakaian secara tidak sah macam-macam jenis obatobat terlarang. "Perkembangan teknologi bukan hanya berdampak positif, bahkan juga bisa berdampak buruk. Dengan perkembangan teknologi menimbulkan adanya peningkatan masalah kejahatan dengan menggunakan modus operasi yang canggih. Hal itulah yang merupakan tantangan untuk aparat penegak hukum untuk mampu menciptakan pencegahannya, khususnya dalam kasus obat-obatan terlarang dan narkotika.

Di Indonesia permasalahan peredaran dan penyalahgunaan narkotika sudah memperlihatkan peningkatan signifikan, yang sangat dikhawatirkan dapat membahayakan hidup para warga masyarakat Indonesia, serta penyebarannya tidak hanya sebagai tempat singgah dalam peredaran dan penyalahgunaan norkotika, namun sudah menjadi sarang penyalur dan sudah dijadikan lokasi untuk memproduksi narkotika secara ilegal. Awalnya narkotika hanya digunakan sebagai alat pengobatan. Namun, seiring perkembangan zaman, narkotika disalahgunakan untuk hal-hal buruk yang sebenernya dalam dunia kedokteran narkotika dipergunakan ke pasien untuk pembiusan sebelum proses operasi. Sebelumnya, narkotika di Indonesia dianggap legal keberadaannya hal ini dibuktikan dengan adanya "UndangUndang Nomor 35 Tahun 2009 tentang Narkotika (UU Narkotika)" yang sebelumnya telah menggantikan "Undang-Undang Nomor 22 Tahun 1997 tentang Narkotika” yang melarang penggunaannya dilakukan tanpa izin.

Dijelaskan narkotika ialah, zat yang asalnya dari tanaman, baik yang sintesis dan semisintesis, yang memiliki efek untuk perubahan atau penurunan kesadaran, mengurangi dan menghilangkan rasa nyeri, hilangnya rasa, serta bisa menimbulkan rasa ketergantungan, yang dibedakan ke 
dalam golongan-golongan yang sudah dijelaskan dalam Undang-Undang Narkotika Pasal 1 ayat (1) Selanjutnya, dijelaskan di Pasal 1 angka 15 penyalahguna ialah orang yang menggunakan narkotika tanpa hak atau melawan hukum.

"Penyalahgunaan narkotika di Indonesia termasuk dalam tindak pidana narkotika. Perbedaan bukan tindak pidana atau perbuatan tindak pidana ialah apakah perbuatan itu dijatuhi sanksi pidana atau tidak dijatuhi sanksi pidana." Penyalahgunaan narkotika sudah lama menjadi suatu permasalahan utama di beberapa negara, baik negara yang sedang berkembang seperti Indonesia maupun negara yang sudah maju sekalipun. Seperti yang kita ketahui, permasalahan narkotika adalah permasalahan yang cukup menarik banyak perhatian dari berbagai kalangan baik kalangan awam hingga kalangan pemerintahan. Ini diakibatkan karna narkotika adalah benda yang merusak pemakainya abila tidak digunakan sesuai dengan dosisnya. Bagi para pengedarnya, narkotika memberikan keuntungan yang banyak yang menyebabkan kejahatan ini sering dilakukan.

"Pengedaran narkotika yang sedang marak di Idonesia sungguh bertolak belakang dari tujuan pembangunan nasional yaitu mewujudkan manusia Indonesia seutuhnya dan masyarakat Indonesia seluruhnya yang tertib, adil, makmur, sejahtera, dan damai berdasarkan Pancasila dan Undang-Undang Dasar Negara Republik Indonesia Tahun 1945. Dampak penyalahgunaan narkotika langsung berdampak kepada para penggunanya dan kepada masyarakat umum. Untuk individu akan berdampak bagi kesehatan baik jasmani maupun rohani. Sedangkan dampak untuk masyarakat ialah meningkatnya kriminalitas dan kemerosotan moral. Guna menertibkan permasalahan diatas, kehadiran dari hukum pidana sangat dibutuhkan. Hukum pidana sebagai salah satu dari bagian hukum pada dasarnya tidak menunjukkan perbedaan dengan hukum-hukum lain, bahwa semua hukum tersebut memuat peraturan yang menjamin norma-norma dalam suatu peraturan hokum dapat ditaati oleh seluruh warga masyarakat. 
"Pengaturan tentang narkotika berdasarkan UU Narkotika, memiliki tujuan untuk menjamin kecukupannya guna untuk kepentingan ilmu pengetahuan dan kesehatan serta mencegah penyelewengan narkotika, dan memberantas penyaluran narkoba secara ilegal. Petugas penegak hukum yang bertugas untuk kasus tindak pidana terhadap penyalahgunaan narkotika adalah poliisi, jaksa, hakim, dan petugas dari Lembaga Pemasyarakatan." "Salah satu dari aparat penegak hokum diatas yaitu kepolisiian sebagai petugas penyidik dalam melaksanakan penyelidikan sehingga harus bekerjakeras untuk menemukan semua bukti yang cukup sehingga dapat dilengkapi oleh JPU pada saat kasus tersebut diadili di pengadilan." Namun hal itu hanya tertulis dalam prakternya saja, realitanya hal tersebut tidak tercapai. Penyebabnya ada pada mental yang goyah oleh petugas penegak hukum.

Tugas dari polisi sebagai penegak dan pelaksana hokum adalah untuk mengamankan keamanan Negara Kesatuan Republik Indonesia. Dalam "Undang-Undang Nomor 22 Tahun 2002 tentang Kepolisian Negara Republik Indonesia" polisi juga diberi kewenangan untuk melakukan pemberantasan dan pencegahan tindak pidana. Diatur juga tentang Kode Etik Profesi dalam "Peraturan Kepala Kepolisian Negara Republik Indonesia Polri." Keberadaan polisi adalah inti dari pelaksanaan sistem peradilan serta wajib melaksanakan wewenang dan tugasnya sebagai penegak hokum. Tetapi tidak dipungkiri juga ada beberapa oknum yang menyalahgunakan kewenangnya yaitu mengonsumsi dan memperjuaalkan barang haram tersebut.

Seperti kasus yang ditemukan di Pengadilan Negeri Jakarta Timur terdapat suatu tindak pidana penyalahgunaan narkotika yang dilakukan oleh aparat penegak hukum salah satunya yaitu anggota polri atas nama MANAT SILABAN selaku anggota polri dimana terdakwa telah melakukan tindak pidana penyalahgunaan narkotika Golongan I Nomor urut 8 dengan jenis ganja seberat bruto 0,51 (nol koma lima puluh satu) gram yang selanjutnya 
ganja tersebut disembunyikan dilipatan saputangan dengan berat netto keseluruhannya 0,2891 (nol koma dua ribu delapan ratus sembilan puluh satu) gram.

Dalam pesidangan terdakwa oleh JPU dituntut atau didakwakan dengan tuntutan atau dakwaan alternatif yang diantaranya pertama yaitu "Pasal 111 ayat (1) UU Narkotika yang meyatakan bahwa terdapat suatu perbuatan tanpa hak atau melawan hukum memiliki, menyimpan, menguasai atau menyediakan narkotika golongan I dalam bentuk tanaman," atau selanjutnya dakwaan kedua yaitu "Pasal 127 ayat (1) huruf a UU Narkotika yang menjelaskan terdapat suatu perbuatan penyalahgunaan narkotika golongan I untuk dirinya sendiri." Setelah persidangan berjalan kemudian hakim memutuskan dengan pertimbangannya bahwa perbuatan terdakwa terbukti secara sah dan dinyakinkan pelaku berbuat tindak pidana yang diatur dalam "Pasal 127 ayat (1) huruf a UU Narkotika." Kemudian dalam putusannya terdakwa dijatuhkan dengan hukuman pidana penjara 1 (satu) tahun 2 (dua) bulan.

Selanjutnya masih di wilayah hukum yang sama terdapat juga suatu tindak pidana yang dilakukan dengan atas nama JEPRI MAHA PUTRA selaku anggota polri dimana terdakwa sudah terbukti secara sah dan siyakinkan atas kesalahan telah melakukan tindak pidana penyalahgunaan narkotika golongan I jenis sabu, berat netto seluruhnya 0,1509 (nol koma seribu lima ratus sembilan) dalam 1 (satu) plastik klip yang kemudian sabu tersebut dibagi menjadi 2 (dua) plastik klip berisi sabu dan kedua plastik klip tersebut disimpan dalam kotak warna merah kombinasi gold.

Dalam persidangan terdakwa oleh jaksa peuntut umum dituntut atau didakwa dengan 3 (tiga) tuntutan atau dakwaan alternatif diantaranya pertama yaitu "Pasal 114 ayat (1) Jo Pasal 132 ayat (1) UU Narkotika yang menyatakan bahwa terdapat suatu perbuatan permufakatan jahat dalam tindak pidana narkotika dengan menawarkan, membeli, menerima, menjual, menjadi perantara dalam jual beli narkotika golongan I," atau dakwaan 
kedua yaitu "Pasal 112 ayat (1) Jo Pasal 132 ayat (1) UU Narkotika yang menyatakan bahwa terdapat suatu permufakatan jahat untuk berbuat tindak pidana dengan menyimpan, menguasai, memiliki, atau menyediakan narkotika golongan I bukan tanaman," atau dakwaan ketiga yaitu "Pasal 127 ayat (1) huruf a UU Narkotika yang menyatakan bahwa terdapat suatu perbuatan penyalahgunaan narkotika golongan I untuk dirinya sendiri." Selanjutnya, dalam putusannya terdakwa terbukti secara sah dan meyakinkan melakukan tindak pidana sebagaimana yang telah disebutkan dalam dakwaan ketiga yaitu "Pasal 127 ayat (1) UU Narkotika" dan hakim menjatuhkan pidana penjara selama 10 (sepuluh) bulan dan memerintahkan terdakwa agar menjalani sisa hukumannya dengan menjalani rehabilitasi medis pada Balai Rehabilitasi Narkotika Nasional Jakarta.

"Jika dilihat dari kasus diatas, maka hal tersebut jelas bisa menimbulkan berkurangnya rasa kepercayaan masyarakat kepada aparat penegak hukum untuk menjalankan tugasnya untuk menjamin dan memberikan kepastian hukum serta memberikan perlindungan hukum terhadap masyarakat, Karena jika dilihat dari kasus diatas polisi sudah melakukan penyelewengan tugas, jabatan dan kewenangnya. Dimana seharusnya merekalah yang memberi contoh dan panutan yang baik serta ikut terjun langsung ke dalam kegiatan untuk memberntas narkoba. Tetapi jika mereka sebaliknya malah menggunakan dan mengedarkan narkotika, maka sudah pasti menimbulkan anggapan atau pandangan buruk kepada aparat kepolisan.

Berbagai upaya yang telah dilakukan oleh institusi kepolisian dalam rangka meminimalisir bahkan menghilangkan adanya keterlibatan anggota polisi terhadap masalah narkotika, baik dalam bentuk pemberian pembekalan yang disampaikan pada saat dilaksanakanya pendidikan pembentukan Bintara maupun Perwira, sampai dengan upaya tindakan tegas bagi anggota yang terbukti terlibat dalam penyalahgunaan narkotika melalui proses peradilan umum dan diperberat dengan mengajukanya kesidang 
Kode Etik Profesi Polri yang sanksi hukumanya hingga pemecatan atau pemberhentian dengan tidak hormat dari dinas kepolisian. Kurangnya pengawasan dari institusi penegak hokum ialah latar belakang penyalahgunaan obat-obatan terlarang yang dilakukan oleh oknom kepolisan. Akhirnya menimbulkan anggapan pesimis dari kesuksesan aparat kepolisian untuk pemberantasan penyalahgunaan dan peredaran narkoba, yang akhirnya menimbulkan saran dari masyarakat awam yang tidak sedikit agar dikehendakinya penetapan hukuman yang berat bukan hanya surat peringatan untuk para aparat polisi yang melanggarnya.

Sehingga diharpkan dapat tercapainya visi misi dari penetapan sanksi pidana yang dimana untuk menimbulkan efek jera kepada semua orang yang sudah melanggar peraturan tindak pidana tanpa melihat dari latar belakang orang yang melakukan tindak pidana itu, hal ini diharapkan bisa menjadi sarana penegakan hukum pidana oleh para aparat kepolisian. Terlebih lagi yang melakukan perbuatan tindak pidana itu ialah berasal dari aparat kepolisian. Sudah pasti yang diharapkan ialah pertanggungjawaban dalam bentuk sanksi, baik pidana ataupun penetapan sanksi oleh instansi yang terlibat agar dijatuhkan sanksi yang berat agar hal ini bisa dijadikan pengingat oleh para aparatur negara untuk tidak melakukan kesalahan yang sama."

Berdasarkan uraian diatas, Penulis tertarik untuk mengkaji perkara tindak pidana narkotika yang menyeret aparat kepolisian sebagai tersangkanya yang hasil penelitianya akan dituangkan dalam bentuk karya ilmiah berupa skripsi dengan judul "Analisis Pertanggungjawaban Pidana Bagi Anggota Polri Yang Melakukan Tindak Pidana Penyalahgunaan Narkotika Berdasarkan Undang-Undang Nomor 35 Tahun 2009 Tentang Narkotika."

\section{B. Perumusan Masalah}


Berdasarkan uraian yang telah dijabarkan dalam latar belakang, maka Penulis merumuskan permasalahan sebagai berikut:

1. Bagaimana mekanisme proses hukum yang dilakukan oleh anggota polri yang melakukan tindak pidana penyalahgunaan narkotika?

2. Bagaimanakah pertanggungjawaban pidana bagi anggota polri yang melakukan tindak pidana penyalahgunaan narkotika berdasarkan UU Narkotika?

\section{Metode Penelitian}

"Metode merupakan suatu unsur mutlak yang harus ada dalam suatu penetilitan yang berfungsi untuk mengembangkan ilmu pengetahuan. Untuk mengetahui permasalahan dan supaya penulis dapat melaksanakan evaluasi dari masalah yang sudah dijelaskan diatas," sehingga dalam pengumpulan bahan-bahan, fakta-fakta, dan data yang diperlukan penulis menggunakan metode yaitu sebagai berikut:

1. Tipe Penelitian

"Tipe penelitian yang digunakan pada penelitian ini bersifat yuridis normatif, karena didasarkan pada metode, sistematika dan pemikiran tertentu dengan tujuan mempelajari suatu data yang akurat dan relevan dengan permasalahan yang diteliti maka penulis menggunakan metodelogi penelitian hukum normatif dengan pendekatan studi kepustakaan dengan menggunakan bahan pustaka." Dalam penelitian ini penulis juga akan menggunakan pendekatan kasus.

2. Jenis dan Sumber Data

Sebagaimana jenis penelitian yang digunakan adalah penelitian hukum normative. Sumber data yang digunakan antara lain: 
a. "Bahan Hukum Primer, bahan hukum yang terdiri atas peraturan perundang-undangan, risalah resmi, putusan pengadilan dan dokumen resmi negara." Untuk bahan hukum primer penulis menggunakan peraturan perundang-undangan berupa, "Kitab Undang-Undang Hukum Pidana (KUHP), Kitab Undang-Undang Hukum Acara Pidana (KUHAP), UU Narkotika, UU Kepolisian, PERKAP KEPP" dan yang berkaitan dengan permasalahan kebijakan hukum pidana terhadap pengaturan penjatuhan hukuman terhadap tindak pidana narkotika di Indonesia.

"Bahan hukum sekunder yaitu bahan hukum yang terdiri atas buku atau jurnal hukum yang berisi mengenai asas hukum, doktrin, hasil penelitian hukum, kamus hukum, ensiklopedia hukum serta wawancara dengan narasumber seorang ahli hukum."

b. "Bahan nonhukum, bahan penelitian yang terdiri dari buku teks bukan hukum terkait dengan penelitian seperti, kamus bahasa dan sebagainya untuk mendukung proses analisis hukum."

3. Teknik Pengumpulan Data

Dalam pengumpulan data penulisan ilmiah ini, penulis menggunakan cara pengumpulan data dengan studi pustaka terhadap bahan-bahan hukum primer, bahan hukum sekunder dan bahan nonhukum, serta dengan melakukan wawancara. Adapun pengumpulan data melalui wawancara dilakukan dengan mengunjungi beberapa pakar maupun narasumber untuk mendapatkan bahan hukum primer yang berkaitan dengan penelitian yang sedang dilakukan.

4. Teknik Analisis Data

Data-data yang telah terkumpul kemudian akan diolah, dan hasil pengolahan data tersebut dianalisis dengan teori yang didapatkan sebelumnya. Teknik analisis data yang digunakan dalam penelitian ini adalah penelitian hukum yang bersifat preskriptif. Dalam penelitian preskriptif, penulis akan memberikan argumentasi atas hasil yang 
diperoleh melalui sumber-sumber penelitian. Dalam menganalisis data dalam penelitian ini, penulis menggunakan 1 (satu) pendekatan yaitu pendekatan perundang-undangan (Statute Approach) .

"Dalam penggunaan pendekatan ini, peneliti perlu untuk memahami hierarki atau susunan, dan asas-asas dalam peraturan perundang-undangan. Pendekatan ini dilakukan dengan menelaah semua undang-undang dan regulasi yang bersangkut paut dengan isu hukum yang sedang ditangani."

\section{PEMBAHASAN}

\section{A. Mekanisme Proses Hukum Bagi Anggota Polisi Yang Melakukan} Tindak Pidana Penyalahgunaan Narkotika

Berdasarkan kasus yang telah dijelaskan sebelumnya aparat polisi yang terseret kasus tindak pidana narkotika sudah dijelaskan dalam "Pasal 29 ayat 1 UU Kepolisian bahwa Anggota Kepolisian Negara Republik Indonesia tunduk pada peradilan umum," maka terhadap anggota polisi yang melakukan atau terjerat dalam tindak pidana wajib menjalankan proses hukum sesuai dengan acara yang telah ada pengaturannya dalam peradilan umum. "Pemberian sanksi untuk para aparat kepolisian yang telah terbukti berbuat tindak pidana khususnya tindak pidana narkotika maka penyelesain perkaranya sama dengan masyarakat pada umumnya yaitu melalui peradilan umum."

Dalam kasus polisi yang melakukan perbuatan tindak pidana dengan mengonsumsi narkotika dan dijelaskan dalam kasus yang ditemukan di Pengadilan Negeri Jakarta Timur berupa 2 putusan pengadilan yaitu “Putusan Nomor 1057/Pid.Sus/2018/PN.Jkt.Tim" dimana Manat Silaban (terdakwa) selaku anggota polisi dan "Putusan Nomor 906/Pid.Sus/2018/PN.Jkt.Tim.” dimana Jepri Maha putra (terdakwa) selaku anggota polisi telah terbukti bersalah melakukan suatu perbuatan pidana yang diatur dalam undang-undang secara khusus yaitu dalam UU 
Narkotika yang didalamnya terdapat ancaman atau sanksi bagi pelanggar. Keduanya terbukti melakukan suatu perbuatan pidana yaitu sebagaimana yang telah diatur dalam "Pasal 127 ayat 1 huruf a yang menyatakan bahwa setiap penyalahguna Narkotika Golonga I bagi diri sendiri dipidana dan dalam pasal tersebut juga terdapat ancaman pidana penjaranya paling lama 4 (empat) tahun." Sebelumnya telah dijelaskan pula bahwa tindak pidana atau yang disebut perbuatan pidana oleh Moeljatno yaitu segala perbuatan yang oleh suatu aturan dilarang dan diancam pidana. Perbuatan yang telah dilakukan oleh terdakwa Manat Silaban dan Jepri Maha Putra yang merupakan penyalahguna Narkotika Golongan I bagi diri sendiri sudah jelas dilarang dan diancam pidana oleh suatu aturan, selain itu juga mengandung unsur melawan hukum. Dengan begitu perbuatan tersebut dapat dinyatakan sebagai tindak pidana atau perbuatan pidana.

Pengaturan hukum pidana di Indonesia mengenal hukum pidana umum yaitu peraturan yang ada dalam KUHP dan hukum pidana khusus yang pengaturannya terdapat diluar KUHP atau terdapat pengaturannya dalam undang-undang khusus. Perbuatan pidana yang dilakukan oleh kedua anggota polisi dalam kasus yang telah dijelaskan diatas tentunya melanggar UU Narkotika, karena adanya salah satu kejahatan menyangkut penyalahgunaan narkotika yang berdampak buruk dan merupakan bahaya yang sangat besar bagi kehidupan masyarakat, bangsa, manusia, dan negara serta ketahanan nasional sebagaimana yang telah disebutkan dalam pertimbangan dikeluarkannya "Undang-Undang Nomor 35 Tahun 2009 tentang Narkotika." Dengan adanya suatu tiindak pidana yang dilakukan oleh kedua anggota polisi tersebut, maka hukum harus ditegakan sebagaimana mestinya.

"Menurut Syafruddin Ainor Rapier selaku Hakim Pengadilan Negeri Jakarta Timur, terkait aparat penegak hukum yang menyalahgunakan narkoba tetap diberlakukan atau diproses sama dengan masyarakat biasa dan tidak ada pembeda dalam pelaksanaan proses peradilan di peradilan 
umum. Anggota polisi yang terjerat dalam tindak pidana selain diproses melalui peradilan umum, anggota polisi yang melakukan tindak pidana juga akan ada tambahan lain yaitu dari internal kepolisian sendiri yang berupa penegakan hukum melalui sidang kode etik yang diatur dalam Peraturan Kepala Kepolisian Republik Indonesia Nomor 14 Tahun 2011 tentang Kode Etik Kepolisian Negara Republik Indonesia.” Mengenai proses hukum yang dilalui oleh anggota kepolisian yang melakukan tindak pidana dapat diuraikan dalam beberapa proses yaitu di internal kepolisian dan di peradilan umum yang diantaranya sebagai berikut:

1. Internal Kepolisian

Mengenai hal-hal yang terkait terhadap aparat polisi yang terseret tindak pidana dilakukan proses penegakan Kode Etikdi Kepolisian yang terdapat pengaturannya dalam "Perkap Nomor 14 Tahun 2011 tentang Kode Etik Profesi Polri (PERKAP KEPP)." Dalam "Pasal 17 ayat 1 Perkap Nomor 14 Tahun 2011 tentang Kode Etik Profesi Polri yang berhak melakukan penegakan kode etik adalah:
a. Propam Polri;
b. Komisi Kode Etik Profesi (KKEP);
c. Komisi Banding;
d. Pengembangan fungsi hukum Polri;
e. SDM Polri;
f. Propam Polri dibidang Rehabilitasi;"

Terkait dengan anggota polisi yang melakukan tindak pidana narkotika, orang tersebut juga melanggar Kode Etik Profesi Polisi (KEPP), ketika polisi melakukan tindak pidana narkotika yang diutamakan proses peradilan umum. "Sementara itu Polisi yang melakukan tindak pidana narkotika itu diproses hingga ada putusan pengadilan yang tetap." Berdasarkan "Pasal 17 ayat 2 penegakan KEPP dilaksanakan melalui: 
a. Pemeriksaan pendahuluan yaitu dalam PERKAP KEPP Pasal 17 ayat 3 menyatakan bahwa, pemeriksaan yang dilakukan dengan cara audit pemeriksaan, investigasi, dan pemberkasan oleh fungsi Propam Polri bidang Pertanggungjawaban Profesi.

b. Sidang Komisi Kode Etik Polri (KKEP) yaitu dalam PERKAP KEPP Pasal 17 ayat 4 menyatakan bahwa, Sidang KKEP dijalankan oleh KKEP guna memeriksa dan memutus perkara pelanggaran yang dilakukan oleh terduga pelanggar.

c. Sidang komisi banding yaitu dalam PERKAP KEPP Pasal 17 ayat 5, dilakukan oleh Komisi Banding guna memeriksa dan memutus keberatan yang diajukan oleh pelanggar.

d. Penetapan administrasi penjatuhan hukuman dilakukan oleh fungsi Sumber Daya Manusia Polri setelah didapatkan putusan dari atasan Ankum sebagaimana disebutkan dalam PERKAP KEPP Pasal 17 ayat 6.

e. Pengawasan pelaksanaan putusan dilakukan oleh fungsi Propam Polri yang menangani bidang rehabilitasi untuk para personel sebagaimana disebut dalam PERKAP KEPP Pasal 17 ayat 7.

f. Rehabilitasi personel."

2. Peradilan Umum

Berdasarkan Putusan Pengadilan Negeri Jakarta Timur dalam "Putusan Nomor 1057/Pid.Sus/2018/PN.Jkt.Tim" dan "Putusan Nomor 906/Pid.Sus/2018/PN.Jkt.Tim.” didalamnya “terkandung sistematik berasal bagian-bagian penyokongnya yakni Kejaksaan, Pengadilan, Kepolisian, dan Lembaga Pemasyarakatan, yang secara keseluruhan ialah satu bagian yang berupaya mewujudkan masukan menjadi luaran yang merupakan visi misi dari sistematik peradilan pidana dalam proses pemidanaan yaitu menangani kejahatan atau mengkontrol segala tindak pidana yang masih berada dalam titik toleransi masyarakat." Berdasarkan teori pemidanaan juga menyatakan bahwa 
pemidanaan merupakan upaya terakhir untuk membuat para warga melaksanakan tindakan tertentu seperti yang diinginkan.

"Menurut Adam Chazawi dalam bukunya, negara melalui alatalatnya diberikan kewenangan dan hak untuk menjalankan maupun manjatuhkan pidana." Sebagaimana telah dijelaksan dalam teori pemidanaan, pemidanaan merupakan salah satu pembalasan bagi seseorang dalam melakukan tindak pidana dan juga pemidanaan sebagai tujuan agar seseorang tidak melakukan suatu tindak pidana, maka dari itu pemidanaan dapat dijalankan agar seseorang merasa jera dan tidak melakukan tindak pidana lagi. Berikut diuraikan pula proses peradilan umum yaitu:

a. Tahap Penyelidikan dan Penyidikan

Dari sederetan tugas kepolisian, salah satu tugas yang mencuri banyak perhatian adalah tugas untuk menegakkan hukum. Sebagai pemegang kewenang untuk penegakan hukum, tugas kepolisian telah dicantumkan dalam KUHAP. Penyelidikan sendiri telah terdapat penjelasannya dalam "Pasal 1 angka 5 KUHAP", sedangkan penyidikan telah dijelaskan dalam "Pasal 1 angka 2 KUHAP."

Dalam rangka menjalankan pekerjaannya kepolisian mempunyai fungsi yang berdasarkan "Pasal 2 UU Kepolisian, yaitu memelihara keamanan dan ketertiban masyarakat; penegakan dan perlindungan hukum; pengayoman dan pelayanan masyarakat." Penyelidikan dilakukan apabila ada indikasi polisi telah melakukan tindak pidana narkotika, biasanya diketahui saat tes urine secara berkala yang dilakukan kepolisian apabila hasilnya positif, dilakukan pengecekkan ulang dan apabila hasilnya positif lagi, maka dilaksanakan pengembangan kasus agar dapat ditentukan apakah ia patut diduga menyalahgunakan narkotika atau tidak, apabila benar maka kemudian dilakukan penyidikan. 
1) Penindakan

a) Penangkapan dan Penggeledahan

Berdasarkan "Pasal 1 angka 20 KUHAP" telah dijelaskan mengenai penangkapan. Dalam hal telah dilakukan penyelidikan oleh penyidik dan telah ditemukan "bukti permulaan yang cukup" maka penyelidik yang akan melakukan pemanggilan terhadap tersangka pelaku tindak pidana narkotika sebanyak 2 (dua) kali secara sah berturutturut. Apabila tidak memenuhi panggilan tanpa alasan maka dilakukan penangkapan disertai dengan surat penangkapan, biasanya penangkapan ini dibarengi dengan penggeledahan dan dalam penggeledahan ini sering ditemukan alat buktinya yang disini biasanya adalah narkotika. Hasil dari penggeledahan tersebut dan penemuan tersangka yang kemudian dibawa ke Polres Jakarta Timur untuk dilakukan serangkaian tindakan lain.

b) Pemanggilan dan Penahanan

"Berdasarkan Pasal 1 angka 21 KUHAP" telah dijelaskan mengenai penahanan. Penahanan dapat membantu penyidikan oleh penyidik dalam memeriksa tersangka atau terdakwa. Penahanan terhadap polisi yang melakukan tindak pidana narkotika sama halnya dengan masyarakat pada umumnya, penahanan untuk memperoleh keterangan mengenai tindak pidana narkotika yang dilakukannya.

c) Penyitaan

Penyitaan dijelaskan dalam "Pasal 1 angka 16 KUHAP”. Penyitaan ini dilakukan oleh penyidik dengan surat izin pengadilan negeri setempat atau apabila dalam keadaan yang mendesak penyidik dapat melakukan 
penyitaan terlebih dahulu hanya atas benda bergerak dan untuk itu wajib segera melaporkan kepada ketua pengadilan negeri setempat guna memperoleh persetujuannya.

d) Pemeriksaan

(1) Pemeriksaan Saksi-Saksi

Dalam "Pasal 1 angka 26 KUHAP telah dijelaskan mengenai pengertian saksi. Pemeriksaan saksi-saksi mempermudah proses penyidikan yaitu berupa keterangan saksi untuk menemukan bukti." Saksi tindak pidana narkotika berdasarkan putusan yang ditemukan di Pengadilan Negeri Jakarta Timur dari lingkungan tersangka yaitu lingkungan teman sekantor yang menggunakan narkotika atau lingkungan di sekitar tempat tinggal. Jadi saksi-saksi ini bisa berasal dari internal ataupun dari luar instansi kepolisian.

(2) Pemeriksaan Ahli

"Pemeriksaan ahli dilaksanakan dengan mendengarkan keterangan ahli sebagaimana yang telah dijelaskan mengenai keterangan ahli dalam Pasal 1 angka 29 KUHAP." Guna keterangan ahli dalam pemeriksaan tersangka atau terdakwa ini yaitu untuk mengetahui tentang barang sitaan atau barang bukti yang telah diperoleh masuk kedalam golongan narkotika jenis apa. Mekanisme ini polres Jakarta Timur mengirimkan barang bukti ke BARESKRIM Polri, barang bukti dicek dengan menjelaskan berat, jenis barang, narkotika masuk golongan apa, urine positif atau negatif.

(3) Pemerikaan Tersangka 
Dalam "Pasal 1 angka 14 KUHAP telah dijelaskan mengenai tersangka".Keterangan tersangka merupakan terpenting karena dia yang melakukan tindak pidana narkotika. Dalam hal pelakunya seorang anggota kepolisian selalu mengakui perbuatannya.

e) Penyelesaian dan Penyerahan Berkas Perkara

Menurut Didit Koko Prastowo selaku jaksa yang menuntut dalam kasus penyalahgunaan narkotika oleh kepolisian, pelimpahan tersangka ke JPU pada saat proses penyidikan telah dianggap apabila penuntut umum menyatakan bahwa hasil penyidikan sudah lengkap atau P21.

b. Tahap Penuntutan

Dalam "Pasal 1 angka 7 KUHAP telah disebutkan mengenai penuntutan." Penuntut umum melakukan penuntutan didahului dengan prapenuntutan yang tujuannya adalah mengetahui Berita Acara Perkara (BAP) sudah legkap atau belum. "Apabila sudah terkumpul maka dilaksanakannya penuntutan, secepatnya harus langsung diserahkan kepada PN, dengan permintaan untuk cepat diadili perkara tersebut disertai dengan surat dakwaan. Jaksa Penuntut Umum (JPU) dalam memberikan tuntutan kepada anggota polisi yang melakukan tindak pidana narkotika lebih berat karena dia seorang penegak hukum."

c. Pemeriksaan Persidangan

Proses pemeriksaan sidang di pengadilan dimulai dengan penetapan majelis hakim yang dilanjutkan dengan penetapan kapan hari sidang." "Pertimbangan hakim untuk memutus polisi yang melakukan tindak pidana narkotika yang seharusmya adalah memberatkan karena polisi menjadi penegak hukum yang 
mengayomi malah polisi yang melakukan tindak pidana narkotika."

d. Putusan Pengadilan

Putusan pengadilan terhadap aparat hukum yaitu kepolisian yang dalam hal ini telah melakukan tindak pidana narkotika, keduanya menghasilkan putusa pemiidanaan yang merupakan isi putusan hakom yang menyimpulkan suatu perinta kepada terdakwa agar menjalani hukoman atas perbuatan yang sudah dilakukan berdasarkan amar putusan. Berdasarkan kasus dalam putusan pertama yaitu "Putusan Nomor 1057/Pid.Sus/2018/PN.Jkt.Tim" hakim memutus 1 (satu) tahun 2 (dua) bulan penjara dan putusan kedua dengan "Putusan Nomor 906/Pid.Sus/2018/PN.Jkt.Tim" yang diputus 10 (sepuluh) bulan penjara dan rehabilitasi.

"Menurut Syafruddin Ainor Rapier selaku Hakim Pengadilan Negeri Jakarta Timur, ia beranggapan bahwa hakim terkait kasus aparat penegak hukum yang melakukan penyalahgunaan narkotika harus mempertimbangkan profesinya sebagai aparat penegak hukum namun ia malah melanggar hukum untuk dijadikan sebagai hal-hal yang memberatkan." Namun sangat disayangkan dalam “Putusan Nomor 906/Pid.Sus/2018/PN.Jkt.Tim" tidak dinyatakan bahwa profesinya sebagai anggota kepolisian selaku aparat penegak hukum tidak dijadikan pertimbangan sebagai salah satu hal-hal yang memberatkan dalam putusannya.

\section{B. Pertanggungjawaban Pidana Bagi Anggota Polri yang Melakukan} Tindak Pidana Penyalahgunaan Narkotika Berdasarkan UU Narkotika

Sanksi pidana terhadap penyalahgunaan narkotika pada "UndangUndang Nomor 35 Tahun 2009 tentang Narkotika" lebih berat dari Undang-Undang terdahulunya yaitu "Undang-Undang Nomor 22 Tahun 
1997 tentang Narkotika." Perubahan tersebut terlihat dalam pengaturan tanaman yaitu $1 \mathrm{~kg}$ atau 5 batang dan bukan tanaman dengan berat lebih daro 5 (lima) gr. Serta juga pengaturan pidanaa mati terhadap yang memproduksi, mengekspor dan impor, mengedarkan dan menggunakan narkotika pada orang lain. Pidana mati selain diterapkan pada Narkotika Golongan I juga diterapkan dalam Narkotika Golongan II. Ketentuan tersebut diharapkan dapat membuat efek yang sangat jera bagi para pelaku tindak pidana narkotika dan prekursor narkotika. Undang-Undang ini sudah memiliki daya tarik dan daya pengikat dalam hal untuk menegakan hukom terhadap pelaku pidana narkotika.

Dalam hal penerimaan sanksi pidana oleh oknum Polri yang mlakukan tindak pidana narkotika telah tepat dan dapat dikatakan bahwa aparat polisi yang telah menyalahgunakan penggunaan narkotika dapat dipertanggungjawabkan sesuai dengan UU Narkotika. Sesuai dengan apa yang telah dijelaskan dalam bukunya, Moeljatno menyatakan bahwa seseorang telah dapat dipertanggungjawabkan apabila terdapat unsur kesalahan dalam perbuatan yang dilakukannya. Kesalahan sendiri, terdiri dari 2 (dua) jenis yaitu adanya kesengajaan dan adanya kelalaian. Dalam kasus anggota kepolisian yang menyalahgunakan narkotika diatas, terdapat unsur kesalahan yang dilakukan oleh kedua terdakwa yaitu Manat Silaban dan Jepri Maha Putra yakni ia telah mengonsumsi barang haram itu untuk dirinya sendiri tanpaada persetujuan medis (dokter) atau termasuk dalam klasifikasi penyalahgunaan narkotika bagi diri sendiri dan perbuatan tersebut merupakan perbuatan melawan hukum, dengan begitu keduanya dijerat dengan UU Narkotika.

Selain terdapat unsur kesalahan dalam perbuatan yang dilakukannya, seseorang bisa dinyatakan dapat bertanggungjawab jika terdapat unsurunsur Pasal 44 KUHP. Dimana kemampuan bertanggungjawab didasarkan pada keadaan dan kemampuan jiwanya dan bukan kepada keadaan dan kemampuan berfikirnya. Dengan begitu dalam kedua kasus diatas terhadap 
Manat Silaban (terdakwa) dan Jepri Maha Putra (terdakwa) telah tepat untuk diproses secara hukum pidana, karena keduanya tidak dalam keadaan jiwanya cacat dalam pertumbuhan atau terganggu karena penyakit.

“Terhadap anggota kepolisian yang terjerat tindak pidana narkotika tetap diberlakukan UU Narkotika, tidak ada perbedaan dalam proses peradilannya dan diperlakukan sama seperti masyarakat biasa. Anggota kepolisian yang terlibat tindak pidana dan sedang diproses di dalam pengadilan biasanya statusnya diberhentikan sementara dalam pekerjaannya dan bisa juga sampai dilakukan pemecatan apabila memang tidak dapat dipertahankan lagi dalam pekerjaannya. Oknum Polri yang menyalahgunakan obat-obatan terlarang selain dijatuhkan sanksi pidana yang terdapat dalam UU Narkotika, ikut turut dijatuhkan sanksi oleh instansi yang bersangkutan yang dinamakan sanksi admistratif. Sesuai pasal 13 huruf b yang menjelaskan tentang tugas utama Kepolisian Negara Republik Indonesia yaitu menegakan hukum, seluruh aparat kepolisian diharuskan untuk menjalankan penyidikan dan penyelidikan terhadap semua bentuk tindak pidana. Apabila aparat kepolisan sendiri yang melanggar suatu ketentuan yang termasuk dalam tindak pidana maka hal tersebut tidak sesuai dengan tugas pokok dari polri, sebab polrilah yang seharusnya menjadi contoh warga negara Indonesia dalam menegakan hukum dan peraturan-peraturan yang berlaku. Hukom berlaku untuk siapapun yang melanggarnya tanpa terkecuali untuk aparat kepolisian sehingga selain dijatuhkan sanksi yang tterdapat didalam UU Narkotika juga dijatuhkan sanksi administratif bagi aparat yang melanggar dari instansinya masing-masing."

Jika aparat kepolisian terbukti melakukan tindak pidana narkotika, menurut Jaksa Didit Koko Prastowo, oknum tersebut harus tetap dihukum. Penerapan hukum selain UU Narkotika, proses dalam mengadilinya mengacu kepada KUHAP yang bisa telaah dalam ketentuan Undang- 
Undang Kepolisian. Terdapat beberapa sanski yang bisa dijatuhkan kepada aparat kepolisian yaitu:

1. Dikenakan sesuai Peraturan Kepolisian;

2. Dibawa ke sidang profesi atau sidang disiplin yang selanjutnya ancaman hukuman dijatuhakn sesuai dengan putusan dari sidang itu sendiri;

3. Pemberhentian tidak dengan hormat (PTDH);

4. Penurunan pangkat;"

Kesempatan aparat kepolisian dalam penyalahgunakan narkoba sangat besar, karena aparat kepolisian juga belum tentu memiliki iman yang kuat serta mempunyai tugas yang selalu terlibat dalam pemberantasan peredaran gelap narkotika. Sanksi atau hukuman yang diberikan oleh instansi yang berwenang kepada aparat kepolisian yang tebukti menyalahgunakan narkotika harus tegas. Dengan demikian, diharapkan dapat menimbulkan rasa jera bagi mereka untuk melakukan kejahatan narkotika. Harus ada kebijakan khusus dalam menangani hal ini, tidak hanya sanksi berupa pemecatan tetapi juga dikenakan dengan sanksi pidana sesuai dengan peraturan yang berlaku. "Kepada para tersangka penyalagunaan narkotika terdapat beberapa alasam tertentu untuk menambah masa hukumannya, dikarenakan perbuatannya dilakukan tergolong sangat membahayakan kepentingan masyarakat."

Anggota Kepolisian Negara Republik Indonesia tunduk kepada kekuasaan peradilan umum sesuai dengan "Pasal 29 UU Kepolisian",. Oleh karena itu dapat diartikan bahwa anggota Polri termasuk warga sipil dan tidak merupakan subjek dari hukum militer. Akan tetapi terhadap anggota polri diberlakukan Kode Etik Profesi serta Peraturan Disiplin walaupun mereka termasuk warga sipil sebagaimana terdapat dalam "Peraturan Pemerintah Nomor 2 Tahun 2003 ttg Peraturan Disiplin Anggota Kepolisian Negara Republik Indonesia" dan pengaturan 
mengenai Kode Etik Profesi Kepolisian terdapat di "PERKAP Nomor 14 Tahun 2011 ttg Kode Etik Profesi Kepolisian Negara Republik Indonesia."

"Tindak pidana yang dilakukan oleh anggota polisi seperti penyalahgunaan narkotika dijatuhkan sanksi administratif maupun sanksi pidana. Terbukti bersalahnya ataupun tidaknya, oknum polisi tetap harus menjalankan persidangan dalam hal kode etik yang diatur didalam PERKAP Nomor 14 Tahun 2011. "aparat kepolisian yang menyalahgunakan obat-obatan terlarang sudah melenceng dari peraturan mengenai kedisiplinan dan kode etik sesuai dengan yang terdapat dalam Pasal 5 huruf a Peraturan Pemerintah Nomor 2 Tahun 2003 Jo. Pasal 6 dan Pasal 7 PERKAP Nomor 14 Tahun 2011, seluruh aparat kepolisian diharuskan untuk menjaaga tegakanya hukum dan juga melindungan kehormatan, reputasii serta martabat Polri”

Etika profesi kepolisian adalah kristalisasi nilai-nilai Tribata yang didasari dan dimaknai oleh Paancasila yang mengambarkan sikap seluruh aparat kepolisian yang mencangkup etika kenegaraan, etika kelembagn etika kemayarakatan serta etika kepribaian, yang setelah itu dimasukan kedalam Kode Etik Profesi Kepolisian Negara Indoensia. "Dibutuhkan ketelitian dalam penyusunan etika kepolisia karena itu merupakan landasan etika kepolisian. Sebelumnya Tribata memberikan identitas kepada Polri, mengenai penyusnanundang-undang ttg Kepolisian Negara Republik Indonesia. Lalu berubah menjadi kode etik."

"Perbuatan melanggar aturan kode etik dan kedisiplinan akan dperiksa dan apabila memang bersalah maka dapat dijatuhkan hukuman. Penjatuhan sanski disiplin dan juga sanksi pelanggaran kode etik tidak memberikan pengaruh pada tuntutan pidana untuk aparat kepolisian yang terbuti melanggar tindak pidana narkotika dijelaskan didalam Pasal 12 ayat 1 Peraturan Pemerintah Nomor 2 Tahun 2003 Jo. Pasal 28 ayat 2 PERKAP Nomor 14 Tahun 2011. Sehingga, aparat kepolisian yang menyalahgunakan obat-obatan terlarang akan menjalani proses hukum 
acara pidana meskipun sudah dijatuhkan sanksi pelanggaran kode etik serta sanksi disiplin. Selain itu, aparat kepolisian yang diperkirakan menyalahgunakan obat-obatan terlarang sedang berjalan proses penyidikannya dianggap tidak bersalah sampai adanya putusan yang inkrah atau yang sedebut dengan asas praduga tak bersalah seperti yang sudah diatur didalam Pasal 8 ayat 1 Undang-Undang Nomor 48 Tahun 2009 ttg Kekuasaan Kehakiman. Selanjutnya, ia akan diancam dengan pemberhentian secara tidak hormat sesuai Pasal 12 ayat 1 hurf a PP Nmr 1 Tahun 2003 tentang Pemberhentian Anggota Kepolisian Negara Republik Indonesia jika putusan pidana telah inkrah.”

Anggota Polri akan diberhentikan dengan tidak terhormat dari dinas kepolisian apabila memang dibuktikan bersalah berdasarkan putusan pengadilan yang telah mempunyai kekuatan hukum tetap berdasarkan pertimbangan dari pejabat-pejabat berwenang tidak bisa diberikan keringanan agar tetap bisa berada didalam dinas Polri. Pemberhentian tersebut dilaksanakan setelah melewati masa persidangan di Komisi Kode Etik Profesi Kepolisian Negara Republik Indonesia yang dijelaskan didalam Pasal 12 ayat 2 PP Nmr 1 Tahun 2003. Jadi walaupun aparat kepolisian merupakan warga sipil, akantetapi terliahat dari perbedaan proses penyidikan perkara oleh warga negara lain karena anggota Polri juga terikat pada aturan disiplin dan kode etik yang juga harus dipatuhi, serta juga selain tunduk pada peraturan perundang-undangan.

\section{PENUTUP}

Dari pembahasan yang telah diuraikan oleh Penulis pada bab-bab sebelumnya, maka Penulis dapat menarik kesimpulan secara umum yaitu sebagai berikut:

1. Penerapan mekanisme proses hukum pidana yang diterapkan di Pengadilan Negeri Jakarta Timur oleh Hakim terhadap tindak pidana penyalahgunaan narkotika yang dilakukan oleh anggota kepolisian 
dalam Putusan Pengadilan Negeri Jakarta Timur Nomor 1057/Pid.Sus/2018/PN.Jkt.Tim dan Putusan Pengadilan Negeri Jakarta Timur Nomor 906/Pid.Sus/2018/PN.Jkt.Tim. telah tepat, karena anggota kepolisian dalam Pasal 29 UU Kepolisian menyatakan polri tunduk kepada peradilan umum, selain itu tindak pidana yang dilakukan terdakwa telah memenuhi unsur-unsur dari syarat pemidanaan terhadap tindak pidana penyalahgunaan narkotika sebagaimana dimaksud dalam Pasal 127 ayat 1 huruf a UU Narkotika, tidak ada perbedaan proses hukum di pengadilan antara masyarakat biasa dengan anggota polri yang melakukan tindak pidana.

2. Pertimbangan hukum hakim terhadap tindak pidana penyalahgunaan Narkotika terkait dengan hal-hal pemberat bagi anggota kepolisian yang melakukan tindak pidana narkotika dalam Putusan Pengadilan Negeri Jakarta Timur Nomor 1057/Pid.Sus/2018/PN.Jkt.Tim telah tepat, namun dalam memutus Putusan Pengadilan Negeri Jakarta Timur Nomor 906/Pid.Sus/2018/PN.Jkt.Tim. sangat disayangkan sekali Hakim tidak mempertimbangkan terkait pekerjaannya sebagai anggota kepolisian dan memasukan sebagai hal-hal pemberatnya. Dalam hal ini Penulis tidak sependapat dengan tidak digunakannya hal-hal pemberat dalam pertimbangan hukum hakimnya.

3. Dalam hal pertanggungjawaban pidana bagi anggota kepolisian yang melakukan tindak pidana narkotika Penulis sependapat apabila anggota kepolisian tersebut selain dijatuhkan sanksi berupa penjatuhan hukuman pidana penjara juga ditindak lanjuti dalam internal kepolisiannya yaitu salah satunya dengan ditindak ke Sidang KEPP.

\section{B. Saran}

Setelah penulis memberikan kesimpulan seperti yang telah diuraikan diatas, maka berikut ini Penulis akan memberikan saran sebagai berikut:

1. Diperlukan pengawasan terhadap setiap anggota kepolisian untuk direkomendasikan tes kesehatan dan apabila memang terlibat tindak 
pidana narkotika, diperlukan pengawasan dalam pelaksanaan proses penegakan hukum dan sanksi pidana terhadap tindak pidana penggunaan obat-obatan terlarang yang dilakukan oleh aparat kepolisian yang pada akhirnya sanksi tersebut dapat dijatuhkan dengan tegas serta menimbulkan efek jera kepada para pelaku tindak pidana yang dilakukan oleh aparat kepolisian.

2. Anggota polisi serta instansi-instasi terkait diharapkan agar mengintesifkan pengawasan terhadap jalur-jalur yang diduga menjadi jalur tranportasi masuk dan keluarnya peredaran narkotika.

3. Menjatuhkan hukuman seberat-beratnya kepada aparat kepolisian yang melakukan perbuatan tindak pidana khususnya untuk narkotika karena seharusnya anggota kepolisianlah yang menjadi contoh untuk masyarakat dan ini diharapkan menjadi pengingat untuk para anggota kepolisian yang lain.

\section{DAFTAR PUSTAKA}

\section{A. Buku}

Efendi, Erdianto. Hukum Pidana Indonesia. Bandung: PT. Refika Aditama, 2011.

Dirdjosisworo, Soedjono. Narkotika dan Remaja. Cetakan ke-1. Bandung: Alumni, 1997.

Surjoni, A.R. dan Bony Daniel. Komentar dan Pembahasan UU No. 35 Tahun 2009 tentang Narkotika. Jakarta: Sinar Grafika, 2011.

Soekanto, Soerjono. Pengantar Penelitian Hukum. Jakarta: UI Press, 1981.

Marzuki, Peter Mahmud. Penelitian Hukum. Cetakan ke-1. Jakarta: Kencana Prenada Media Group, 2006.

. Penelitian Hukum. Cetakan ke-9. Jakarta:

Prenadamedia Group, 2014. 